\title{
Mesenteric Lesions
}

\section{with Similar or Distinctive}

\section{Appearances on CT}

유사하거나 특이한 CT 소견을 보이는 장간막 병변

\author{
Hwajin Cha, MD (D), Jiyoung Hwang, MD* (D), Seong Sook Hong, MD (D), \\ Eun Ji Lee, MD (D), Hyun-joo Kim, MD (D), Yun-Woo Chang, MD (D) \\ Department of Radiology, Soonchunhyang University College of Medicine, Seoul Hospital, Seoul, \\ Korea
}

The mesentery is a structure comprising a double peritoneal layer that attaches the bowel to the abdominal wall. Mesenteric disease can cause various non-specific clinical symptoms in adults and is sometimes found incidentally during unrelated diagnostic imaging studies. CT plays an essential role in the diagnosis of mesenteric disease, which can present with various radiologic features, including a solid mass, cystic mass, or local or diffuse infiltration on CT. Some mesenteric diseases present with distinctive characteristics, while others share similar findings, thereby complicating their differential diagnosis. Therefore, understanding the radiological findings of mesenteric disease is important for accurate diagnosis and appropriate treatment.

Index terms Mesentery; Abdominal Neoplasm; Diagnosis, Differential;

Tomography, X-Ray Computed

\section{INTRODUCTION}

The mesentery is a fan-shaped double fold of peritoneum that attaches the intestinal loops to the posterior abdominal wall. It contains variable fat tissue through which major arteries, veins, nerves, and lymphatics run to supply the intestines (1). A variety of diseases can occur in the mesentery and present with various radiologic features on CT. Although some mesenteric diseases present with distinctive characteristics, others share similar findings, complicating differential diagnosis. Therefore, understanding the patterns of radiological characteristics on CT offers valuable insights for differential diagnosis of mesenteric disorders. In this article, we classify various mesenteric diseases according to CT appearance and review the radiologic findings of several diseases.
Received February 20, 2019

Revised April 24, 2019

Accepted April 29, 2019

*Corresponding author Jiyoung Hwang, MD Department of Radiology, Soonchunhyang University College of Medicine, Seoul Hospital, 59 Daesagwan-ro, Yongsan-gu, Seoul 04401, Korea.

Tel 82-2-709-9396

Fax 82-2-709-9066

E-mail jy0707hwang@schmc.ac.kr

This is an Open Access article distributed under the terms of the Creative Commons Attribution Non-Commercial License (https://creativecommons.org/ licenses/by-nc/4.0) which permits unrestricted non-commercial use, distribution, and reproduction in any medium, provided the original work is properly cited.

ORCID iDs

Hwajin Cha (D) https:// orcid.org/0000-0002-6292-0350 Jiyoung Hwang (iD https:// orcid.org/0000-0002-3070-4880 Seong Sook Hong (D) https:// orcid.org/0000-0003-2893-6583 Eun Ji Lee (D) https:// orcid.org/0000-0002-4860-2495 Hyun-joo Kim (D) https:// orcid.org/0000-0001-5386-1881 Yun-Woo Chang (D) https:// orcid.org/0000-0001-9704-8112

Recipients of Bronze Award for Best Scientific Exhibition Awards at 2018 KCR Annual Meeting. Invited for the Pictorial Essay. 


\section{SOLID MASSES}

\section{DESMOID TUMOR}

Desmoid tumors are uncommon, benign, non-inflammatory fibroblastic neoplasms that can occur anywhere in the abdomen, abdominal wall, or extra-abdominal tissue (2). These tumors are locally aggressive and sometimes recur but do not metastasize. Compression or invasion of adjacent structures can occur as the tumor grows. Small-bowel mesenteric desmoid tumors occur at a $3.5-5.7 \%$ incidence in patients with familial adenomatous polyposis and Gardner syndrome (3) and develop more frequently after surgery. Pregnancy-related desmoid tumors are typically discovered in the abdominal wall, including the rectus abdominis or oblique muscles. On CT images, they present with a variable appearance. Most mesenteric desmoid tumors appear as a relatively homogeneous soft-tissue mass with well or poorly defined borders and radiating stranding or a "whorled appearance" in the adjacent mesenteric fat (Fig. 1) (4). Variable attenuation can be seen with necrosis or degeneration.

\section{SCLEROSING MESENTERITIS}

Sclerosing mesenteritis is an idiopathic, non-neoplastic, chronic inflammatory condition affecting the mesentery. It has recently been identified as an abdominal component of immunoglobulin G4-related sclerosing disease (5).

From a single clinicopathological entity, three disease-progression phases are identifiable (6). Mesenteric lipodystrophy is dominated by fat necrosis and degeneration of mesenteric fat. During this phase, patients are usually asymptomatic, and no treatment is needed. Mesenteric panniculitis is characterized by chronic inflammatory changes in the mesenteric fat. It usually arises from the small-bowel mesentery and may involve the mesocolon (7), but the omentum or retroperitoneum are rarely affected. The first two disease stages cannot be distinguished in an imaging study, ranging from mesentery haziness to the soft tissue mass at

Fig. 1. Desmoid tumor in a 52-year-old man with a past history of an operation performed 7 years ago. A, B. The contrast-enhanced axial CT image shows a homogeneous soft-tissue mass with a poorly defined border in the pelvic mesentery (A), showing interval growth on a follow-up scan performed 3 months later (B) (arrows).
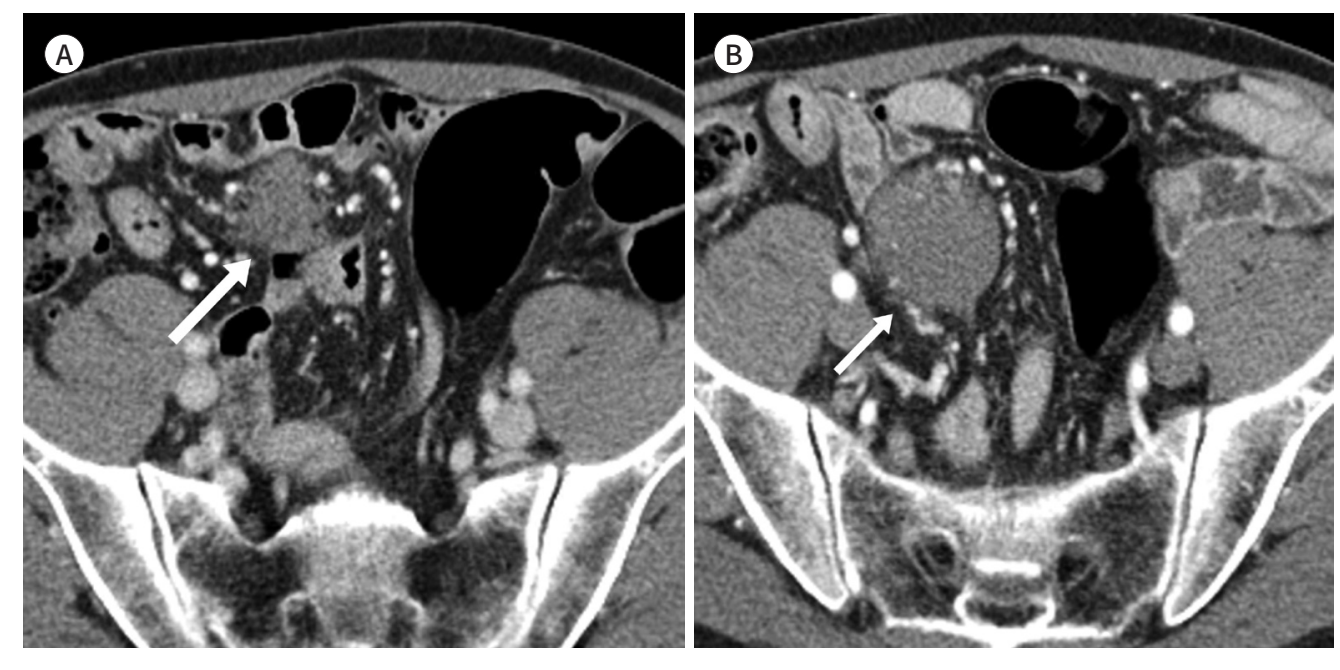
Fig. 2. Immunoglobulin G4-related sclerosing mesenteritis in a 78-year-old woman. A, B. The contrast-enhanced axial and coronal CT images show an irregular and heterogeneous soft-tissue mass in the small bowel mesentery with an intralesional mesenteric vessel (empty arrow in A) and calcifications (arrows in A). The adjacent small intestine shows mild mural thickening, representing small bowel ischemia (arrowheads in A and B).
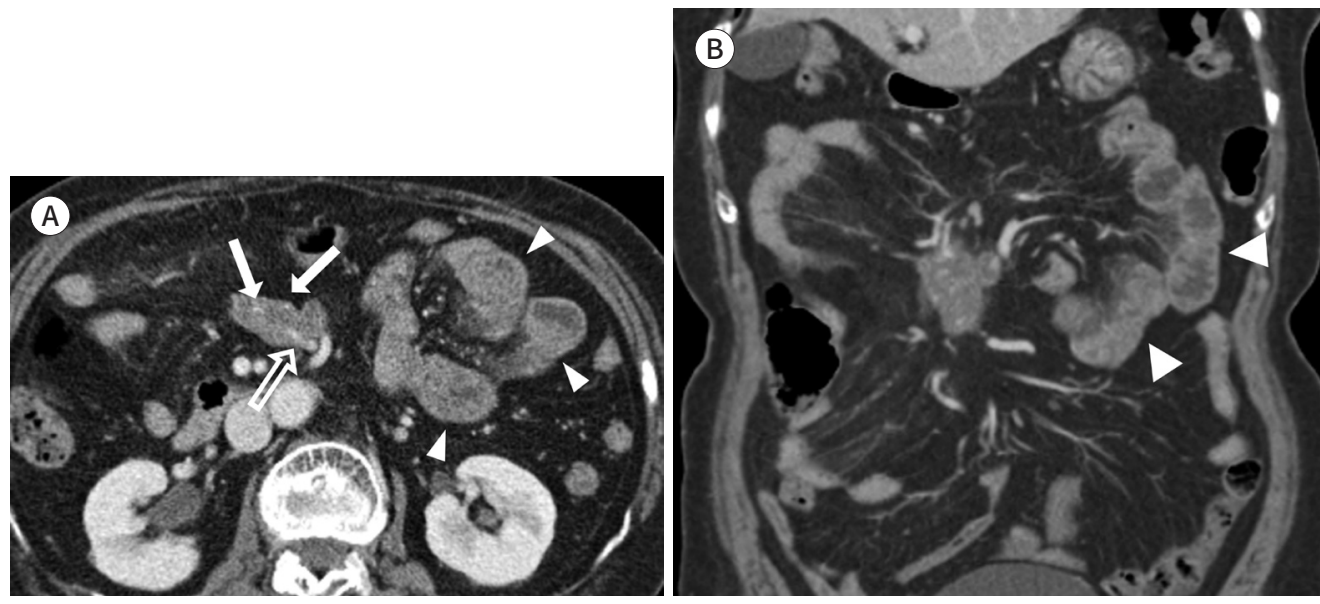

Fig. 3. Sclerosing mesenteritis in a 68-year-old woman. The contrast-enhanced axial CT image shows an illdefined soft-tissue mass in the small bowel mesentery with the fat-ring sign (arrows).

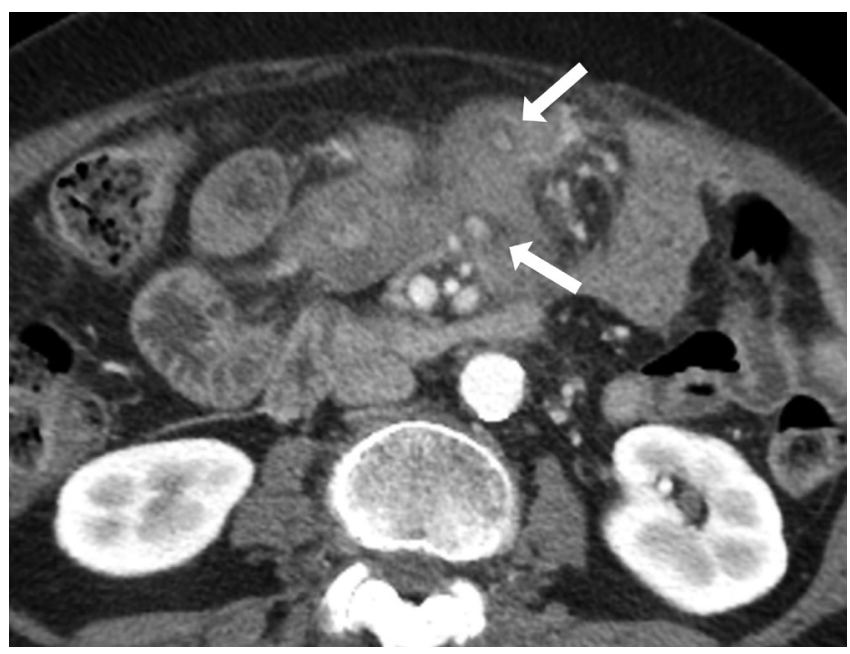

the mesenteric root (Fig. 2) (1). Subtly increased mesentery is described as "misty mesentery," and the "fat-ring sign" is a phenomenon of fatty attenuation preservation, which forms a low attenuated halo around the affected vessel (Fig. 3). As inflammatory reactions progress, collagen deposition, scarring, and fibrosis occur. Retractile mesenteritis, the final disease stage, leads to large mesenteric mass formation and obstructive symptoms. A mesenteric root mass is the most common imaging finding, usually observed as an ill-defined, heterogeneous, and low attenuated mass with occasional calcification and cystic changes (8). Compression of the mesenteric vessels, collateral vessel formation, and bowel ischemia may appear with disease progression. Patients may present with any of the three disease stages, and those stages can also coexist. Even malignancies, such as lymphoma or melanoma, can be associated (9).

\section{GASTROINTESTINAL NEUROENDOCRINE TUMOR}

Gastrointestinal neuroendocrine tumors (NET) are rare, accounting for only 2\% of gastro- 
intestinal tract tumors. However, they are the most common malignant neoplasm of the small bowel, especially the distal ileum (10). The usual pathway for tumor spread is through the mesentery, either by direct extension or local lymphatics. These tumors can be functional or non-functional: functional NETs may present with carcinoid syndrome and are often small at the time of diagnosis. Sometimes a mesenteric mass is detected first, because the primary lesion is too small to observe. Non-functional or malignant NETs are larger at presentation and easier to diagnose. Common imaging findings of the primary tumor are well defined, hypervascular, enhancing, soft-tissue masses or regional wall thickening with radiating strands in the mesenteric fat (Fig. 4). Mesenteric tumor spread manifests as an enhancing soft-tissue mass with strands radiating in the mesenteric fat. Soft-tissue strands result from fibrosis and desmoplastic reactions within the mesenteric fat rather than tumor infiltration. Calcifications may be visible on CT in up to $70 \%$ of cases $(11,12)$.

\section{LYMPHOMA}

Lymphoma is the most common malignant neoplasm of the mesentery (13) and will be discussed in detail later. When lymphoma manifests as a nodal mass in the mesentery, it may mimic the CT appearance of other mesenteric masses including sclerosing mesenteritis or mesenteric NETs.

\section{PARAGANGLIOMA}

Extra-adrenal paragangliomas are rare tumors of neural crest origin. Theoretically, these tumors can arise from any area of the paraganglia, such as the carotid body, jugular foramen, posterior mediastinum, and the abdominal para-aortic area, including the organ of Zuckerkandl (14). Paragangliomas arising in the mesentery are rarely reported (15-17). They are usually nonfunctional and found incidentally or following symptoms related to local tumor growth. Retroperitoneal paragangliomas produce catecholamines in more than half of all

Fig. 4. Intestinal neuroendocrine tumor in a 47-year-old man.

A. The contrast-enhanced axial CT image shows an enhancing soft-tissue mass with focal strands radiating in the mesenteric fat (arrow).

B. A well-defined hypervascular enhancing mass (arrow) is seen in the ileum, indicating the primary intestinal neuroendocrine tumor.
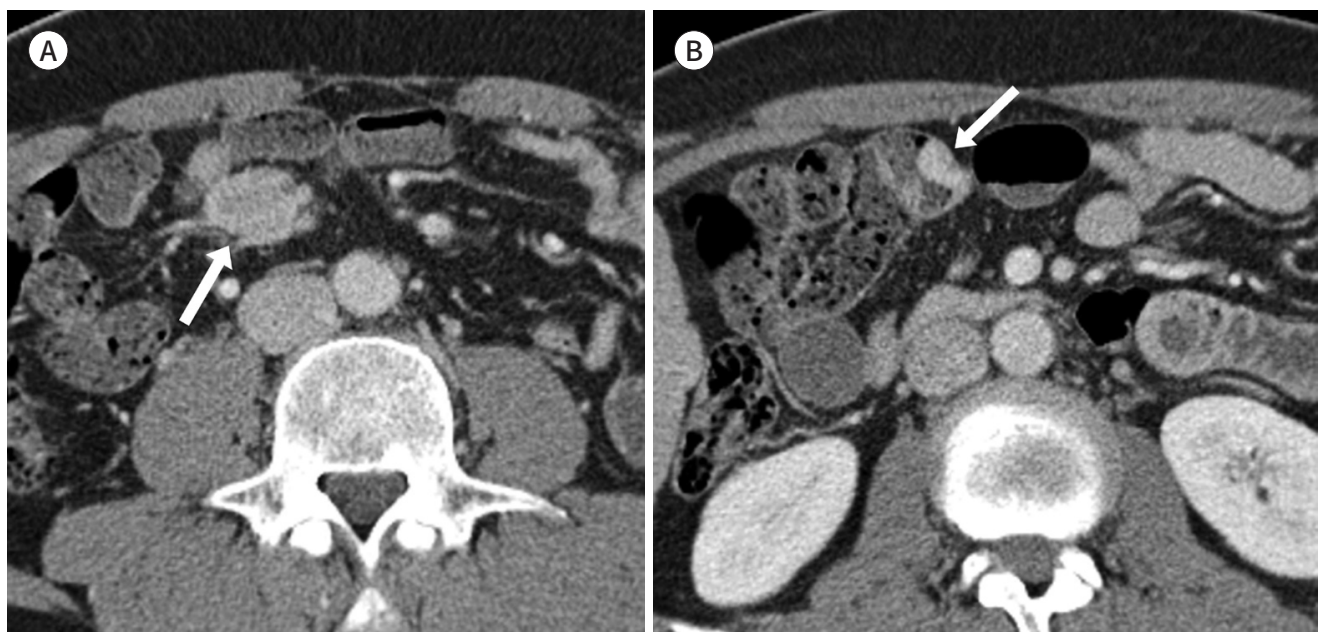
cases, and patients may present with palpitation, headache, and sweating, which are associated with pheochromocytoma. Paragangliomas may be associated with multiple endocrine neoplasia type-2, von Hippel-Lindau disease, Carney triad, or neurofibromatosis type-1 (NF-1) (18). Common CT findings from reported cases of intra-abdominal paragangliomas include smoothly marginated, strongly enhanced tumors containing multiple low-density areas (Fig. 5). In some tumors, focal high attenuation is observed due to acute hemorrhage (19).

\section{LEIOMYOMA}

Leiomyomas are composed of smooth muscle cells and can occur wherever there is a smooth muscle. Leiomyomas most commonly occur in the uterus and can involve the vulva, ovary, urethra, urinary bladder, and retroperitoneum (20). Unusual leiomyoma growth has

Fig. 5. Paraganglioma in a 64-year-old man.

A. The contrast-enhanced axial CT image shows a well-marginated enhancing mass with internal low-attenuation areas (arrow).

B. The internal low-attenuation areas show hyperintensity on the axial T2-weighted MR image (arrow).
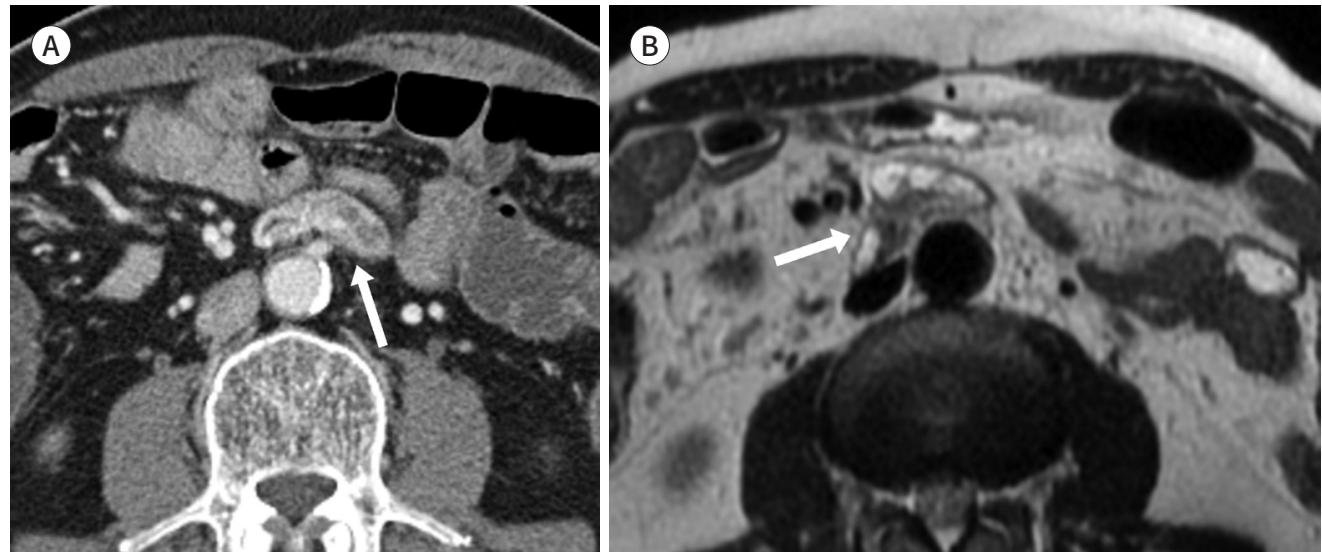

Fig. 6. Leiomyoma in a 49-year-old woman.

A. The contrast-enhanced coronal CT image shows a well-defined enhancing soft-tissue mass with a central low-attenuation area in the right lower abdominal mesentery (arrow). Uterine subserosal leiomyomas (arrowheads) are seen, which show similar attenuation and enhancement to that of the mesenteric mass.

B. On the axial T2-weighted MR image, the mesenteric mass shows a similar low signal intensity to that of the smooth muscle (arrow).
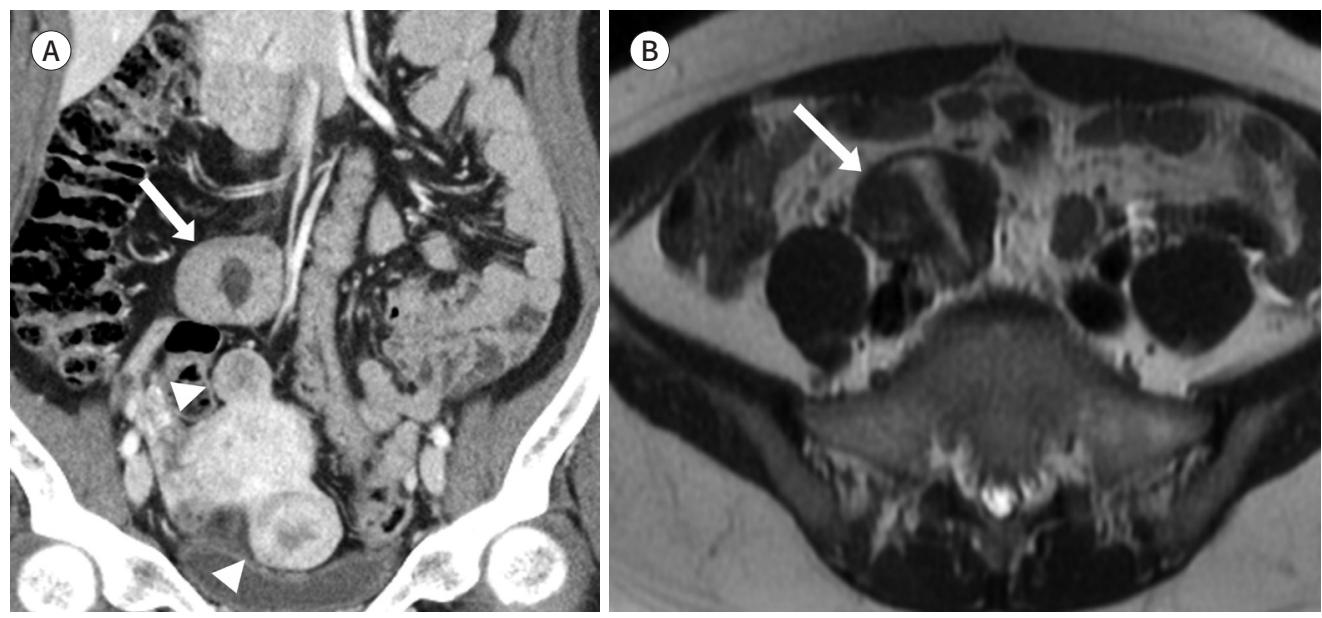
been reported, including disseminated peritoneal leiomyomatosis, benign metastasizing leiomyoma, and intravenous leiomyomatosis (21). All leiomyomas share imaging features regardless of anatomic location (22). They show similar attenuation and enhancement to that of smooth muscle (Fig. 6). Magnetic resonance imaging (MRI) is helpful when tumors present with the same signal intensity as smooth muscle on any MR pulse sequence.

\section{EXTRA-GASTROINTESTINAL GASTROINTESTINAL STROMAL TUMOR}

Extra-gastrointestinal gastrointestinal stromal tumors (GIST) account for 5-10\% of all GISTs (23), which show no relationship to the walls of the hollow viscus of the gastrointestinal tract. They originate from outside the alimentary tract or are detached from the gastrointestinal tract. Most tumors are found in the abdominal wall, including the omentum and mesentery, and are more rarely found the retroperitoneum, liver, or pancreas (24). Radiologic features of extra-gastrointestinal GISTs are similar to those of GIST but vary depending on size and aggressiveness. Usually, large tumors show central necrosis, cystic change, and hemorrhage (Fig. 7) (25).

\section{PLEXIFORM NEUROFIBROMA}

Neurofibromas arise from Schwann cells and fibroblasts and pathognomonic for NF-1. Abdominal involvement of neurofibroma is commonly discovered in the retroperitoneal, mesenteric, and paraspinal regions (26). Neurofibromas that arise from peripheral nerves cross the mesentery and often have a branching or coalescent appearance. They may cause vascular narrowing and compromise blood flow (Fig. 8). Extensive and bilateral mass distribution is difficult to distinguish from lymphoma or the other cystic lesions, and calcification or capsule is unusual. On contrast-enhanced CT scan, plexiform neurofibromas show homogeneously low attenuation in up to $73 \%$ of cases (27), possibly due to cystic degeneration, xanthomatous features, lipid-rich nerve-sheath cells, perineuronal adipose tissue, and hypocellularity. These features are quite characteristic, and a NF-1 diagnosis should be suggested rather than invasive surgical biopsy.

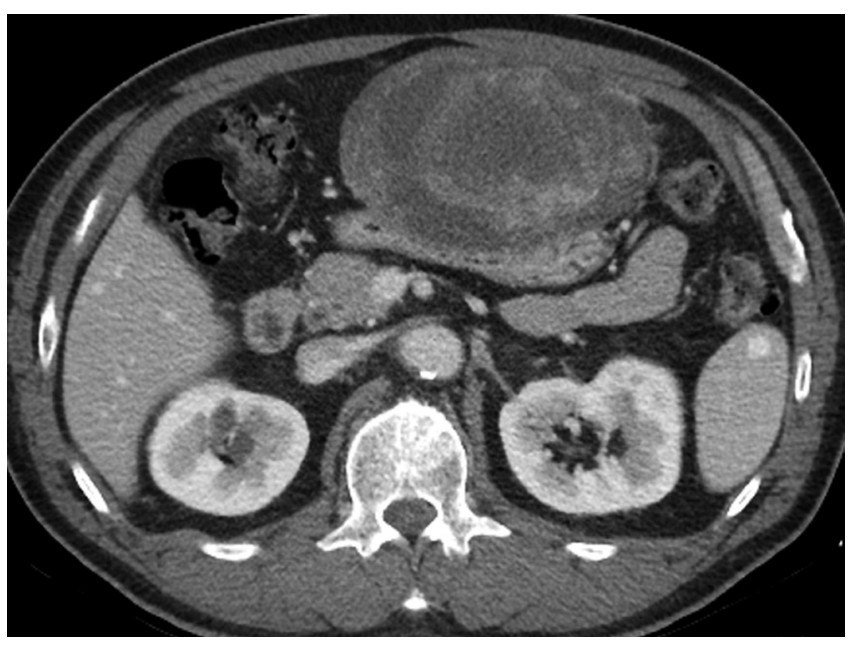

Fig. 7. Extragastrointestinal gastrointestinal stromal tumor in a 62-yearold man. The contrast-enhanced axial CT image shows a large, well-defined heterogeneous mass with central necrosis or cystic change in the greater omentum. A well-defined cystic mass originating from the omentum and adhering to the gastric wall was found on surgery. 


\section{CYSTIC MASS}

\section{CYSTIC LYMPHANGIOMA}

Intra-abdominal cystic lymphangioma is a rare benign tumor of mesenchymal origin that is frequently located in the mesentery. The omentum, mesocolon, and retroperitoneum are less commonly involved. Cystic lymphangioma originates from either congenital malformation of the lymphatic system or a benign neoplasm (28). Cystic lymphangiomas typically present as large, thin-walled multiloculated cysts that are filled with proteinaceous eosinophilic fluid (29). Cystic walls are very thin and often imperceptible. On CT images, cystic lymphangioma may show homogeneously low attenuation that is less than that of water due to its chylous contents (Fig. 9) (30). If complications such as hemorrhage or infection co-occur, attenuation may be altered. Calcification may also occur but is uncommon.

\section{CYSTIC MESOTHELIOMA}

Cystic mesothelioma is a rare benign neoplasm of the peritoneal mesothelium. It has no malignant potential but recurs in 25-50\% of cases (31). Peritoneal mesotheliomas occur more frequently in reproductive-age women and are more likely to involve the pelvis, making them difficult to distinguish from ovarian tumors. Differential diagnoses of cystic mesothelioma include lymphangioma, pseudomyxoma peritonei, peritoneal carcinomatosis, and cystic adenomatoid tumor. CT findings of cystic mesothelioma include multiple grape-like

Fig. 8. Plexiform neurofibroma in a 21 year-old woman with neurofibromatosis type 1 . The contrast-enhanced coronal CT image shows a branching or coalescent, homogeneously low-attenuation mass at the porta hepatis, periceliac area, and mesentery, encasing the portal veins, celiac trunk, and mesenteric vessels.

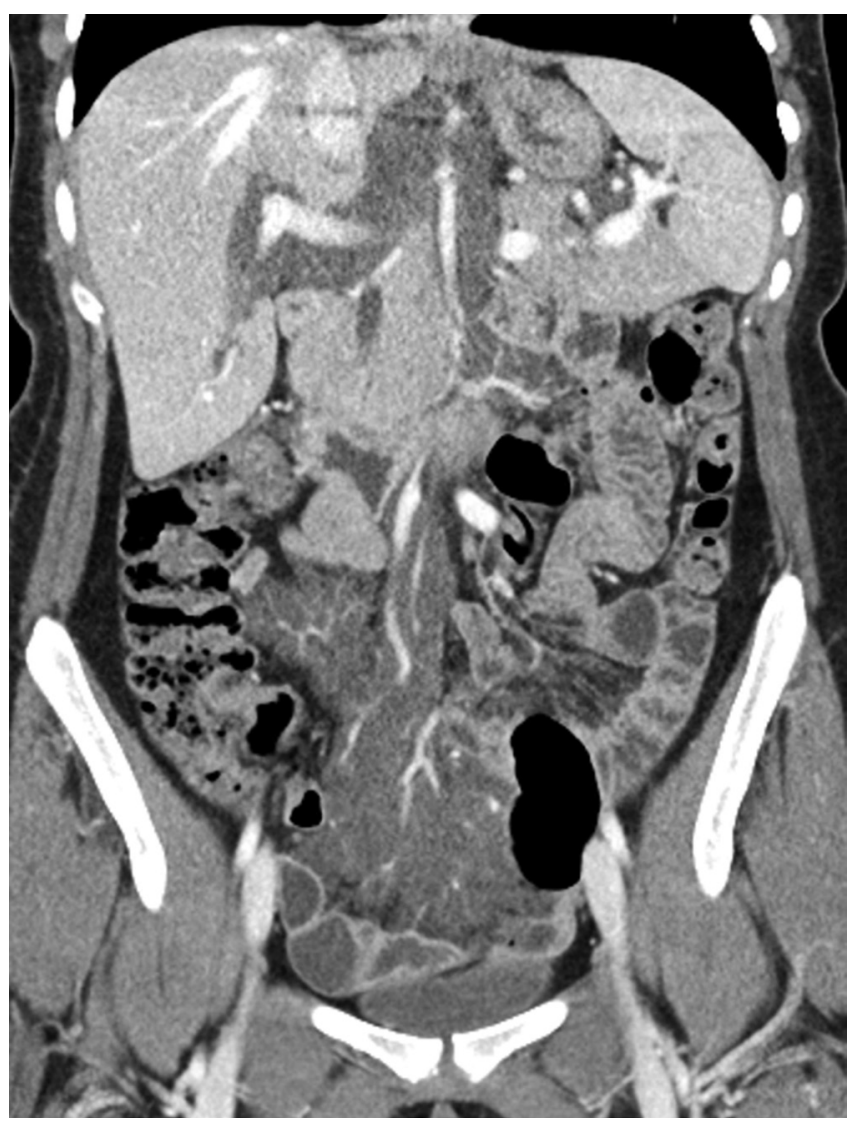




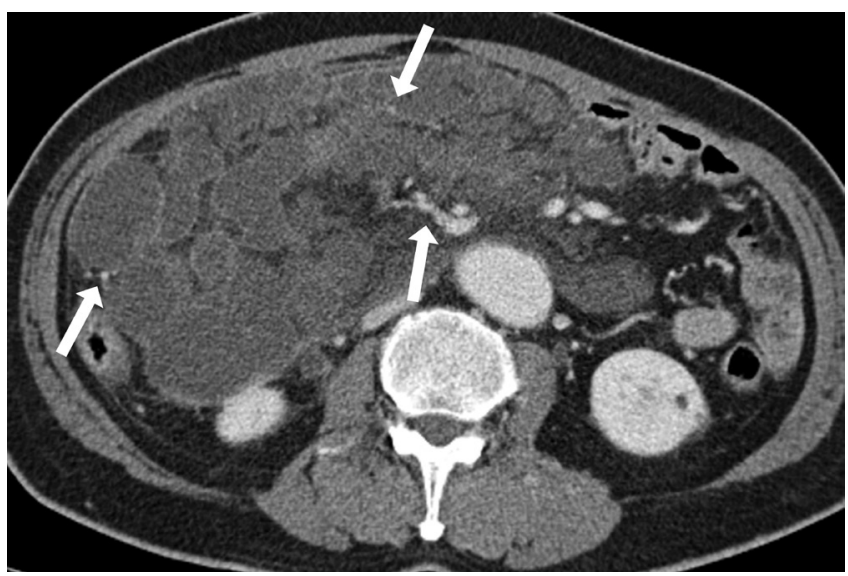

Fig. 9. Cystic lymphangioma in a 69year-old man with abdominal distension and discomfort. The contrastenhanced axial CT image shows large, thin-walled, multilobulated cysts in the right abdominal mesentery. The mesenteric vessels are seen coursing between the cystic locules (arrows).

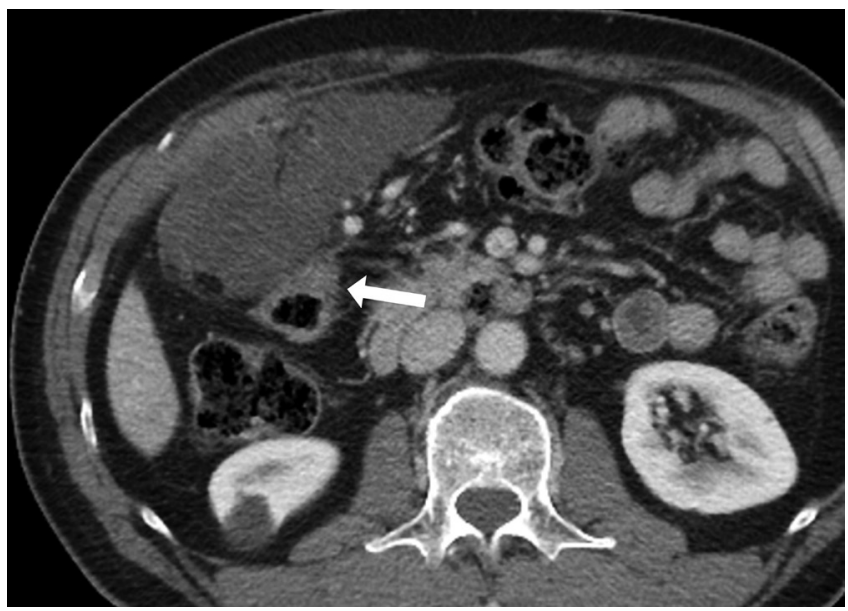

Fig. 10. Cystic mesothelioma in a 64year-old man. The contrast-enhanced axial CT image shows a grape-like cluster of thin-walled cysts. A spaceoccupying low-density cystic lesion is seen in the right abdominal mesentery. The cystic lesion does not present a mass effect on the adjacent bowel (arrow).

clusters of thin-walled cysts filled with serous fluid, separated by varying amounts of fibrous tissue (Fig. 10). The size of a single cyst ranges from millimeters to several centimeters (32). Calcifications are rarely seen. These tumors typically do not produce a mass effect on adjacent structures. Scalloping of surrounding structures, increased attenuation, calcification, or prominent soft tissue components are suggestive of a malignant condition rather than cystic mesothelioma.

\section{CAVERNOUS HEMANGIOMA}

The most common type of hemangioma that involves the mesentery is a cavernous hemangioma (33), which consists of large blood-filled sinuses lined by endothelial tissue. Mesenteric cavernous hemangiomas can occur in any location and most commonly emerge from the middle of the small intestine (34). Common presenting symptoms are a palpable mass, abdominal pain, fullness, and, occasionally, massive hemoperitoneum. On CT, mesenteric cavernous hemangioma appears as a poorly defined bordered mass that does not invade neighboring organs. Thrombus formation from sinusoidal injury can lead to hyalinization and calcification. Phlebolith growth, resulting from secondary calcification of this core, produces typical CT findings (Fig. 11) (35). 
Fig. 11. Cavernous hemangioma in a 56-year-old woman. The contrastenhanced axial CT image shows a poorly-defined soft-tissue mass with multiple phleboliths (arrows). The mass does not invade the adjacent organs in the left lower abdominal mesentery.

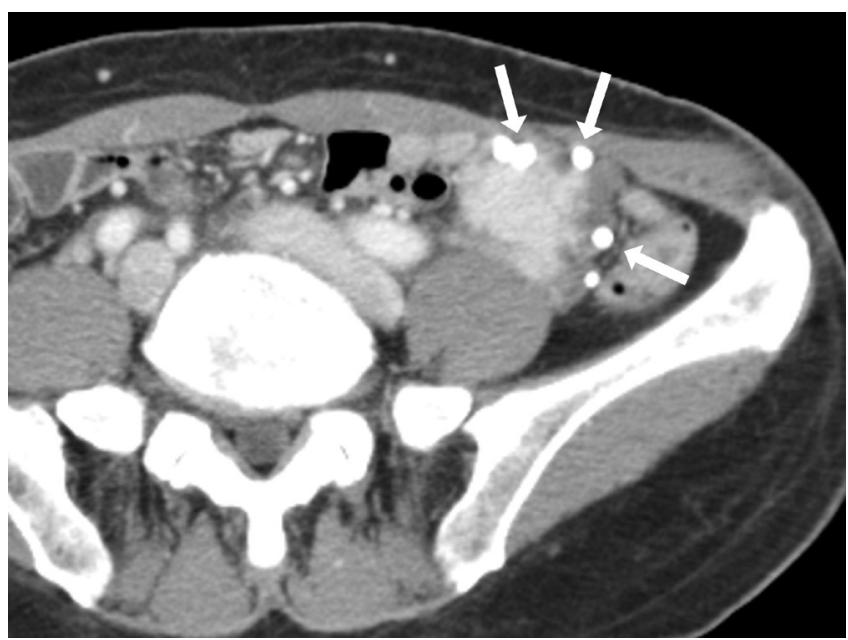

Fig. 12. Tuberculous lymphadenitis with enteritis in a 50-year-old man with active pulmonary tuberculosis and pleurisy.

A, B. The contrast-enhanced coronal CT images show multiple enlarged lymph nodes with central low-attenuation necrosis and peripheral contrast enhancement in the right lower abdominal mesentery (arrows in A). Segmental mural thickening of the distal ileum is noted (arrow in B). Mycobacterium tuberculosis was confirmed on the culture test and on acid-fast bacilli staining of an endoscopic biopsy specimen.
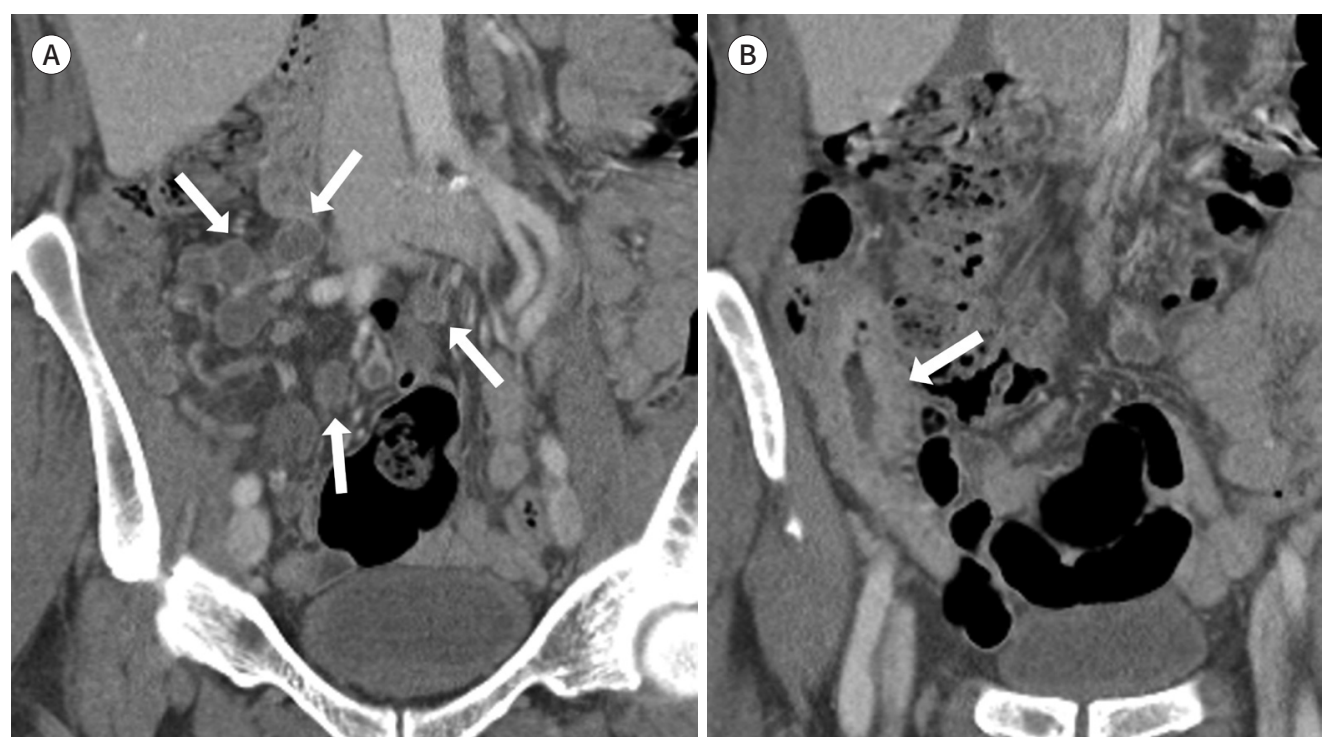

\section{MESENTERIC LYMPHADENOPATHY}

\section{TUBERCULOUS LYMPHADENITIS}

Tuberculous infections of the lymph nodes is more frequently seen in mesenteric, upper and lower para-aortic, periportal, and pancreaticoduodenal areas. Lymphadenopathies show confluence distributions and typically present as central low attenuated necrosis with peripheral contrast enhancement (Fig. 12). Diagnosis of intra-abdominal tuberculous lymphadenitis is challenging because the imaging findings overlap with those of many malignancies, such as metastatic lymph nodes or lymphoma. An invasive procedure, such as endoscopic ultrasonography-guided fine-needle aspiration, and histopathologic examination may be re- 
quired to make an accurate diagnosis.

\section{SARCOIDOSIS}

Sarcoidosis is characterized pathologically by the presence of non-caseating granulomas. Sarcoidosis with pulmonary involvement has been well documented; however, as a systemic granulomatous disease of unknown origin, sarcoidosis presents as an extrathoracic disease in about $40 \%$ of patients. The eyes, skin, lymph nodes, liver, spleen, heart, musculoskeletal system, or nervous system may all be affected. Sarcoidosis rarely involves the alimentary tract. About $10 \%$ of patients with proven sarcoidosis show noncaseating granulomas on gastric mucosal biopsy (36). The stomach is the most frequently affected organ in the gastrointestinal tract (Fig. 13). Although most patients are asymptomatic, some complain of nonspecific symptoms, such as nausea, vomiting, bloating, or epigastric pain. Enlarged lymph nodes are commonly detected. Lymphadenopathy $<2 \mathrm{~cm}$ may be found in the porta hepatis, para-aortic, and celiac areas $(36,37)$. Sarcoidosis with peritoneal involvement is extremely rare. Exudative ascites, multiple granulomatous nodules, or single peritoneal lesions may also be seen.

\section{LYMPHOMA}

Lymphoma is the most common malignant neoplasm of the mesentery, and 30-50\% of mesenteric lymphomas are non-Hodgkin type disease (38). The typical imaging findings for mesenteric lymphoma are multiple, round, mildly homogeneously enhancing masses (39). Conglomerated lymphadenopathy on both sides of the mesenteric vessels without significant vessel caliber change and with an intact perivascular fat border is called "sandwich sign" or "vessel imbedded sign" (Fig. 14). It is commonly accompanied by homogeneously enhancing bulky retroperitoneal adenopathy (40). After treatment, increased inhomogeneity and illdefined infiltration of the mesenteric fat are commonly noted.

Fig. 13. Sarcoidosis in a 37-year-old man.

A. The contrast-enhanced axial CT images show homogeneously enhancing, enlarged lymph nodes in the mesentery.

B. Diffuse mural wall thickening of the stomach is also seen. Sarcoidosis was pathologically proven on an endoscopic stomach biopsy test.

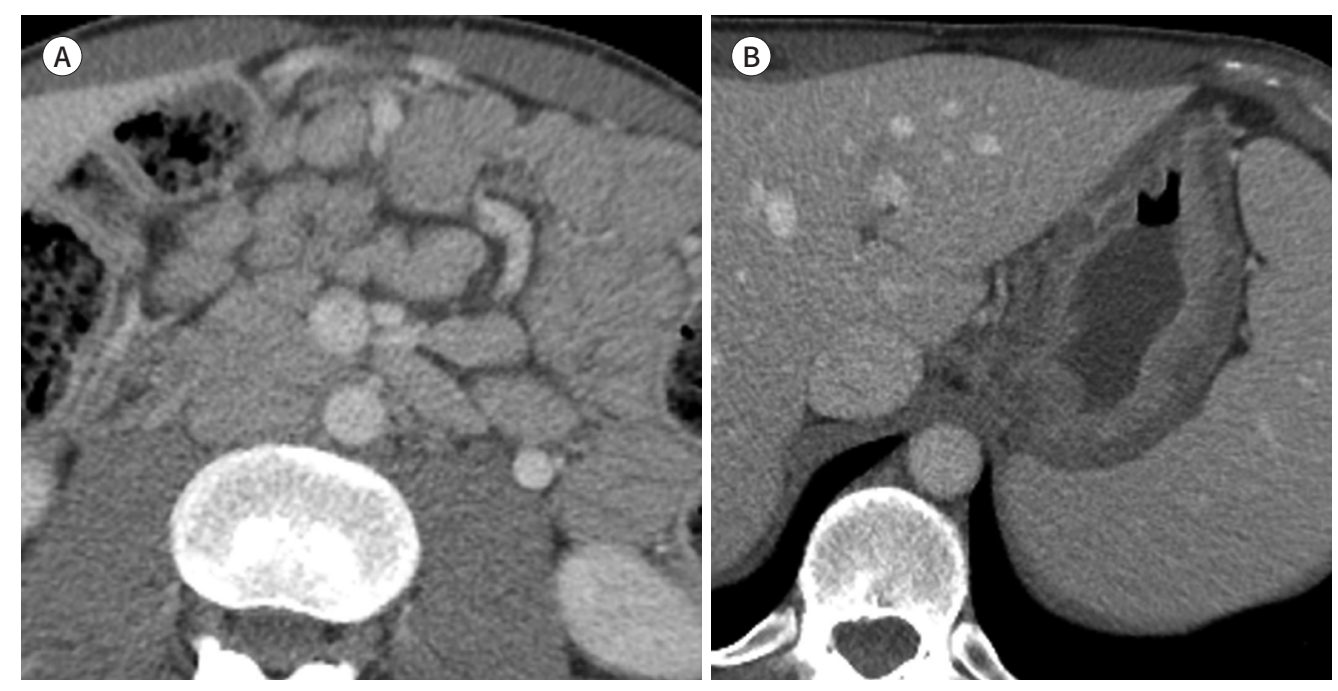


Fig. 14. Extranodal marginal zone Bcell lymphoma of the mucosa-associated lymphoid tissue in a 52-year-old woman. The contrast-enhanced axial CT image shows a homogeneously enhancing mass indicating conglomerated lymphadenopathy, which encases the mesenteric vessels without any caliber change, i.e., the so-called "sandwich sign" (arrow).

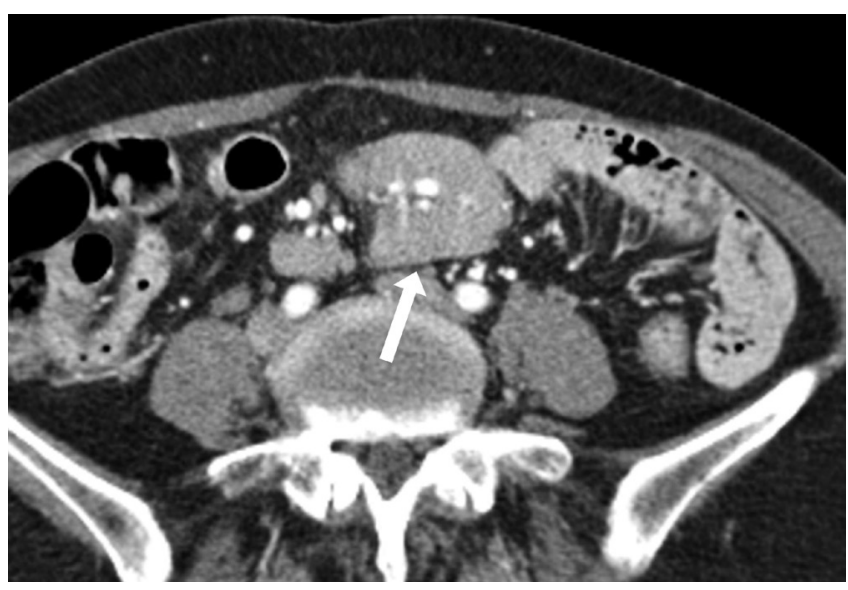

Fig. 15. Tuberculous peritonitis in a 54year-old woman. The contrast-enhanced axial CT image shows a large amount of ascites with smooth and symmetric thickening and contrast enhancement of the peritoneum, which is a relatively characteristic feature of tuberculous peritonitis. The omentum has a smudged or dirty appearance (arrows).

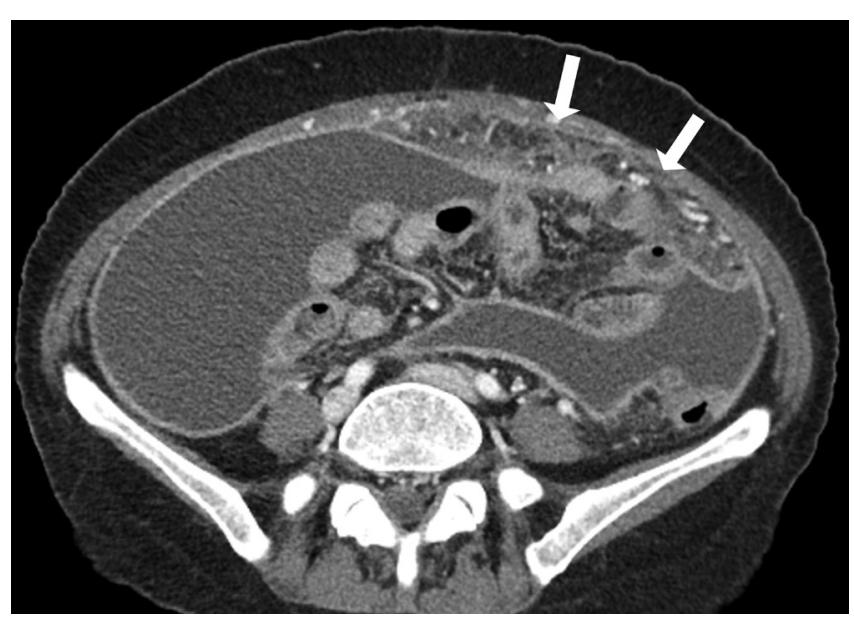

\section{DISSEMINATED DISEASE}

\section{TUBERCULOUS PERITONITIS}

Differentiating tuberculous peritonitis from peritoneal carcinomatosis is quite challenging. Findings suggest that tuberculous peritonitis involves relatively smooth, symmetrical thickening of the peritoneum, high-attenuated ascites, and thickening of the intestinal wall, particularly the terminal ileum and cecum (Fig. 15) (41). Also, if lymphadenopathy with low attenuation is observed, tuberculous lymphadenitis can be suspected $(42,43)$.

\section{INTRAPERITONEAL SEEDING}

The peritoneum is a relatively common site of metastasis, particularly from malignancies originating in the abdomen and pelvis. Presence of peritoneal carcinomatosis indicates advanced disease that is inoperable and has a poor prognosis (44). Intraperitoneal dissemination of a tumor results in nodular omental infiltration, enhancing peritoneal nodules, and irregular peritoneal thickening with malignant ascites (Fig. 16). The stellate appearance of the mesentery is the result of mesenteric masses from tumor deposits within the mesentery (45). Gastric, pancreatic, ovarian, and breast cancers are commonly associated with peritoneal carcinomatosis. Evidence of tumor-seeding nodules in paracolic gutters or the pouch of 
Fig. 16. Gastric cancer with peritoneal carcinomatosis in a 39-year-old man with abdominal pain and weight loss.

A, B. The contrast-enhanced axial CT images show nodular omental infiltration (asterisks in A) and irregular thickening of the peritoneum with moderate amount of ascites. Note the enhancing wall thickening with ulceration in the gastric body, representing the primary gastric cancer (arrow in B).
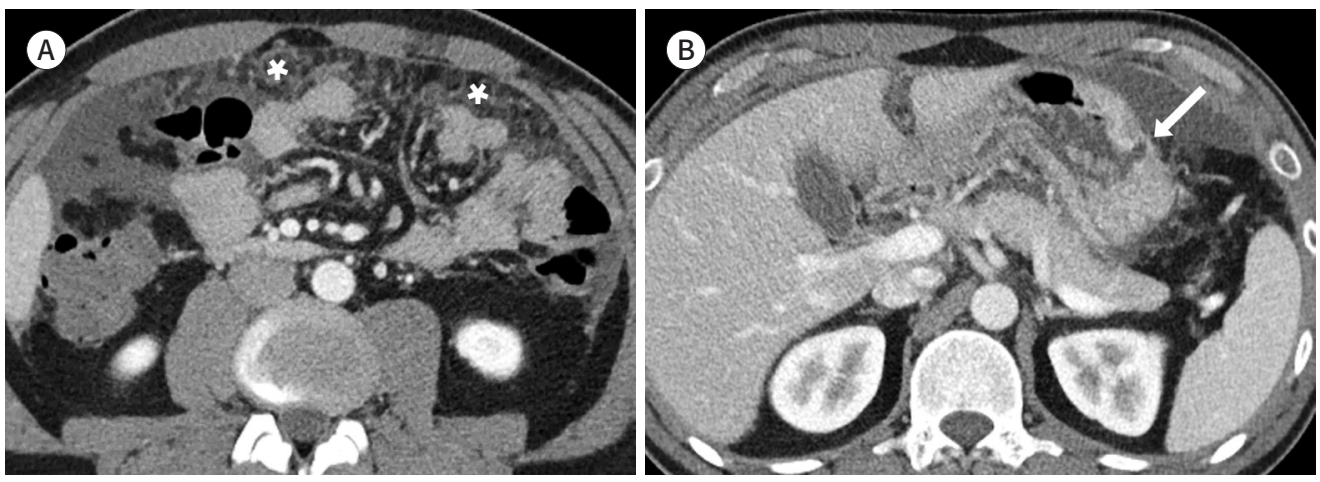

Fig. 17. Refractory peripheral T-cell lymphoma with peritoneal lymphomatosis in a 63-year-old man with unsuccessful chemotherapy.

A, B. The contrast-enhanced axial CT images show enlarged lymph nodes in the retroperitoneum (arrows in A) and multifocal bowel wall thickening (arrowheads in A). Irregular thickening of the peritoneum with ascites is also observed (arrows in B).
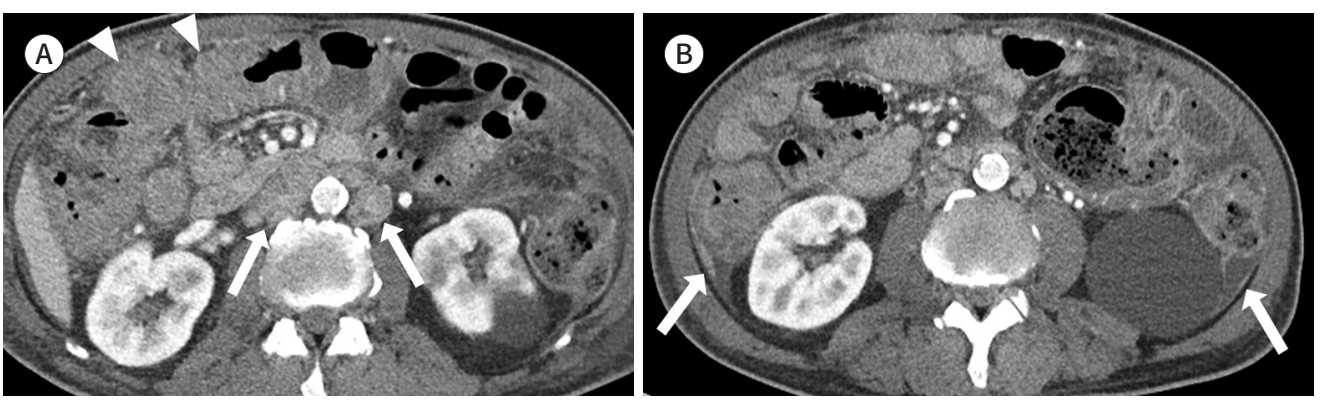

Douglas may offer important diagnostic clues (42, 45).

Peritoneal spread of primary gastrointestinal lymphomas is most frequently seen with non-Hodgkin lymphoma. In previous reports, peritoneal lymphomatosis was most commonly associated with diffuse large B-cell lymphoma (46). Bulky, homogeneous, soft tissue masses in the omentum or diffusely infiltrating peritoneal thickening are characteristic imaging findings of peritoneal lymphomatosis. Ascites may be observed as well. A stellate appearing in the mesentery due to lymphoma infiltration that causes mesentery thickening and stiffness is a frequently encountered feature (38). Differential diagnosis of peritoneal lymphomatosis from peritoneal carcinomatosis or sarcomatosis is difficult. Diffusely enlarged lymph nodes are more suggestive of peritoneal lymphomatosis (Fig. 17), while lymphadenopathy around the primary tumor is usually observed with peritoneal carcinomatosis. In peritoneal sarcomatosis, a bulky and hypervascular mass is common and may be associated with the hemoperitoneum (47).

\section{MALIGNANT PERITONEAL MESOTHELIOMA}

Malignant peritoneal mesothelioma is a rare, usually lethal neoplasm arising from the me- 
sothelial cells that line the serosal surface of the peritoneal cavity. Malignant peritoneal mesothelioma has been reported to be associated with heavy asbestos exposure (48). On CT, findings of malignant mesothelioma range from "dry" type to "wet" type depending on the presence of ascites (31). The typical wet appearance of peritoneal mesotheliomas consists of ascites, nodular peritoneal thickening, and omental masses (Fig. 18). Differential diagnosis of malignant peritoneal mesothelioma includes peritoneal carcinomatosis, serous surface papillary carcinoma, lymphomatosis, and tuberculosis.

\section{SMOOTH MUSCLE TUMOR WITH UNCERTAIN MALIGNANT POTENTIAL}

Smooth muscle tumor with uncertain malignant potentials (STUMP) are not distinguishable from benign leiomyomas or malignant leiomyosarcomas on imaging and are usually distinct in histopathologic analysis only after surgery (49). Most STUMPs are located in the uterus, but they can also be found in the broad ligament, ovaries, cervix, or vaginal canal. Clinical

Fig. 18. Malignant mesothelioma in a 44-year-old man.

A-B. The contrast-enhanced axial CT images show a large amount of ascites, nodular thickening of the peritoneum (arrows in A), and enhancing masses in the mesentery (arrowhead in A) and pelvis (arrow in B), which are findings of "wet-type" malignant mesothelioma.
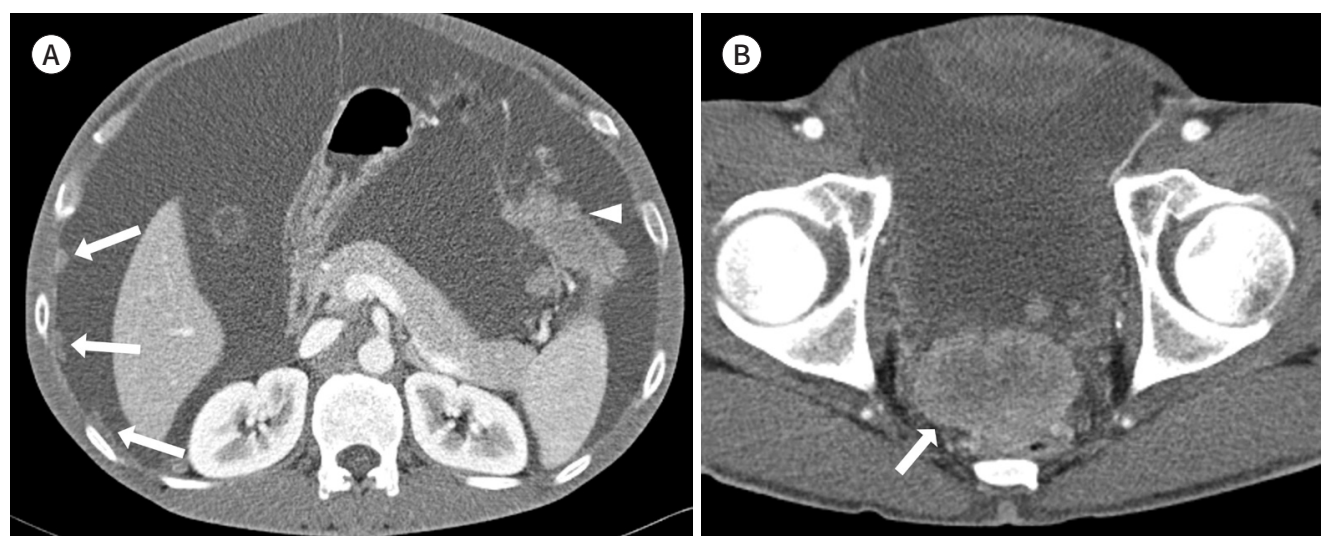

Fig. 19. Smooth muscle tumors with uncertain malignant potential in a 28-year-old woman. A, B. The contrast-enhanced axial CT images show multiple well-circumscribed, strong-enhancing masses in the paracolic gutter (arrow in A), pelvic cavity (arrows in B), and uterus (asterisks in B). These lesions are not diagnosable from leiomyomas on the basis of imaging findings.
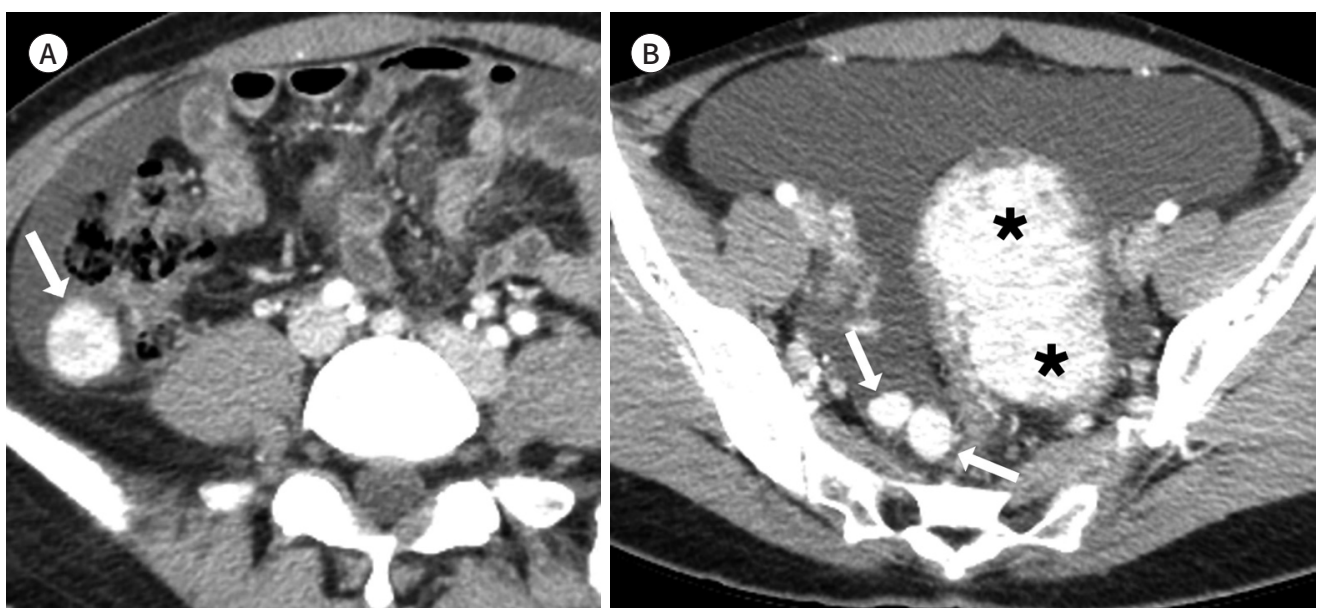
symptoms of STUMP are similar to those of uterine leiomyomas: abnormal vaginal bleeding, anemia, palpable pelvic mass, or compressive symptoms. Clinically, STUMPs may carry a greater risk of recurrence, metastasis, dissemination, and malignant transformation than benign leiomyoma. In clinical practice, ultrasound and MRI are the most accurate and, thus, first-line imaging modalities. Although CT is not a modality of choice for STUMP evaluation, these tumors are incidentally seen as well-circumscribed masses with variable contrast enhancement (Fig. 19).

\section{CONCLUSION}

CT is a useful imaging modality for the diagnosis of mesenteric lesions. Classification of mesenteric masses according to radiologic findings and a systematic approach provides valuable clues to the differential diagnosis of mesenteric lesions found on CT scans.

\section{Author Contributions}

Conceptualization, C.H., H.J.; data curation, C.H., H.J.; investigation, C.H., H.J., L.E.J.; resources, C.H., H.J.; supervision, H.S.S., L.E.J., K.H., C.Y.; validation, H.S.S., L.E.J., K.H., C.Y.; visualization, C.H., H.J., L.E.J.; writing-original draft, C.H., H.J.; and writing-review \& editing, H.J., H.S.S., L.E.J., K.H., C.Y.

\section{Conflicts of Interest}

The authors have no potential conflicts of interest to disclose.

\section{REFERENCES}

1. Sheth S, Horton KM, Garland MR, Fishman EK. Mesenteric neoplasms: CT appearances of primary and secondary tumors and differential diagnosis. Radiographics 2003;23:457-473; quiz 535-536

2. Shinagare AB, Ramaiya NH, Jagannathan JP, Krajewski KM, Giardino AA, Butrynski JE, et al. A to Z of desmoid tumors. AJR Am J Roentgenol 2011;197:W1008-W1014

3. Righetti AE, Jacomini C, Parra RS, De Almeida AL, Rocha JJ, Féres O. Familial adenomatous polyposis and desmoid tumors. Clinics (Sao Paulo) 2011;66:1839-1842

4. Brooks AP, Reznek RH, Nugent K, Farmer KC, Thomson JP, Phillips RK. CT appearances of desmoid tumours in familial adenomatous polyposis: further observations. Clin Radiol 1994;49:601-607

5. Chen TS, Montgomery EA. Are tumefactive lesions classified as sclerosing mesenteritis a subset of IgG4-related sclerosing disorders? J Clin Pathol 2008;61:1093-1097

6. George V, Tammisetti VS, Surabhi VR, Shanbhogue AK. Chronic fibrosing conditions in abdominal imaging. Radiographics 2013;33:1053-1080

7. Levy AD, Rimola J, Mehrotra AK, Sobin LH. From the archives of the AFIP: benign fibrous tumors and tumorlike lesions of the mesentery: radiologic-pathologic correlation. Radiographics 2006;26:245-264

8. Horton KM, Lawler LP, Fishman EK. CT findings in sclerosing mesenteritis (panniculitis): spectrum of disease. Radiographics 2003;23:1561-1567

9. Halligan S, Plumb A, Taylor S. Mesenteric panniculitis: systematic review of cross-sectional imaging findings and risk of subsequent malignancy. Eur Radiol 2016;26:4531-4537

10. Chang S, Choi D, Lee SJ, Lee WJ, Park MH, Kim SW, et al. Neuroendocrine neoplasms of the gastrointestinal tract: classification, pathologic basis, and imaging features. Radiographics 2007;27:1667-1679

11. Sahani DV, Bonaffini PA, Fernández-Del Castillo C, Blake MA. Gastroenteropancreatic neuroendocrine tumors: role of imaging in diagnosis and management. Radiology 2013;266:38-61

12. Tan EH, Tan CH. Imaging of gastroenteropancreatic neuroendocrine tumors. World J Clin Oncol 2011;2:2843

13. Whitley NO, Bohlman ME, Baker LP. CT patterns of mesenteric disease. J Comput Assist Tomogr 1982; 
6:490-496

14. Granger J, Mahapatra R, Hamid B, Gillespie K, Fok M, Vimalachandran D. Incidental mesenteric paraganglioma: a csse report and literature review. Ann Coloproctol 2017:33:197-200

15. Ozkan Z, San Ozdemir C, Yasar G, Altas O, Koc M, Gul Y, et al. An unusual mesenteric tumor 'paraganglioma': a case report. Iran Red Crescent Med J 2014;16:e16837

16. Fujita T, Kamiya K, Takahashi Y, Miyazaki S, lino I, Kikuchi H, et al. Mesenteric paraganglioma: report of a case. World J Gastrointest Surg 2013;5:62-67

17. Kim HI, Koo BK, Lee YJ, Kim JT, Cho YM, Lee KU, et al. A case of paraganglioma arising in the transverse mesocolon. J Korean Soc Endocrinol 2005;20:496-501

18. Erickson D, Kudva YC, Ebersold MJ, Thompson GB, Grant CS, Van Heerden JA, et al. Benign paragangliomas: clinical presentation and treatment outcomes in 236 patients. J Clin Endocrinol Metab 2001;86:52105216

19. Lee KY, Oh YW, Noh HJ, Lee YJ, Yong HS, Kang EY, et al. Extraadrenal paragangliomas of the body: imaging features. AJR Am J Roentgenol 2006;187:492-504

20. Rosica G, Santilli G, Bucari D, Amici B, Bulletti F, Patacchiola F, et al. A case of disseminated peritoneal leiomyomatosis and diffuse uterine leiomyomatosis. Clin Exp Obstet Gynecol 2011;38:84-87

21. Fasih N, Prasad Shanbhogue AK, Macdonald DB, Fraser-Hill MA, Papadatos D, Kielar AZ, et al. Leiomyomas beyond the uterus: unusual locations, rare manifestations. Radiographics 2008;28:1931-1948

22. Julien C, Bourgouin S, Boudin L, Balandraud P. Disseminated peritoneal leiomyomatosis. J Gastrointest Surg 2019;23:605-607

23. Reith JD, Goldblum JR, Lyles RH, Weiss SW. Extragastrointestinal (soft tissue) stromal tumors: an analysis of 48 cases with emphasis on histologic predictors of outcome. Mod Pathol 2000;13:577-585

24. Angelico G, Spadola S, Trombatore C. Clinicopathological and prognostic features of extragastrointestinal stromal tumors of the omentum: a review. J Gastroenterol Res 2017;1:9-13

25. Watal P, Brahmbhatt SG, Thoriya PJ, Bahri NU. Retroperitoneal extragastrointestinal stromal tumor: radiologic pathologic correlation. J Clin Imaging Sci 2014;4:34

26. Bass JC, Korobkin M, Francis IR, Ellis JH, Cohan RH. Retroperitoneal plexiform neurofibromas: CT findings. AJR Am J Roentgenol 1994;163:617-620

27. Fortman BJ, Kuszyk BS, Urban BA, Fishman EK. Neurofibromatosis type 1: a diagnostic mimicker at CT. Radiographics 2001;21:601-612

28. Romeo V, Maurea S, Mainenti PP, Camera L, Aprea G, Cozzolino I, et al. Correlative imaging of cystic lymphangiomas: ultrasound, CT and MRI comparison. Acta Radiol Open 2015;4:2047981614564911

29. Levy AD, Cantisani V, Miettinen M. Abdominal lymphangiomas: imaging features with pathologic correlation. AJR Am J Roentgenol 2004;182:1485-1491

30. Palomeque Jiménez A, Herrera Fernández FA, Calzado Baeza S, Reyes Moreno M. Giant mesenteric cystic lymphangioma as an incidental finding in a young adult. Gastroenterol Hepatol 2014;37:416-417

31. Park JY, Kim KW, Kwon HJ, Park MS, Kwon GY, Jun SY, et al. Peritoneal mesotheliomas: clinicopathologic features, CT findings, and differential diagnosis. AJR Am J Roentgenol 2008;191:814-825

32. Lee R, Tong A, Kurtis B, Gilet AG. Benign multicystic peritoneal mesothelioma: AIRP best cases in radiologic-pathologic correlation. Radiographics 2016;36:407-411

33. Ojili V, Tirumani SH, Gunabushanam G, Nagar A, Surabhi VR, Chintapalli KN, et al. Abdominal hemangiomas: a pictorial review of unusual, atypical, and rare types. Can Assoc Radiol J 2013;64:18-27

34. Ithan M, Oner G, Gök AF, Bulakçı M, Yeğen G. Treatment of atypically-localized cavernous hemangioma in abdomen with atypical pain. Int J Surg Case Rep 2016;25:24-27

35. Si-Mohamed S, Aufort S, Khellaf L, Ramos J, Gasne P, Durand L. Mesenteric cavernous hemangioma: imaging-pathologic correlation. Diagn Interv Imaging 2015;96:495-498

36. Gezer NS, Başara I, Altay C, Harman M, Rocher L, Karabulut N, et al. Abdominal sarcoidosis: cross-sectional imaging findings. Diagn Interv Radiol 2015;21:111-117

37. Warshauer DM, Lee JK. Imaging manifestations of abdominal sarcoidosis. AJR Am J Roentgenol 2004;182: 15-28

38. Lee WK, Lau EW, Duddalwar VA, Stanley AJ, Ho YY. Abdominal manifestations of extranodal lymphoma: spectrum of imaging findings. AJR Am J Roentgenol 2008;191:198-206

39. Manzella A, Borba-Filho P, D'Ippolito G, Farias M. Abdominal manifestations of lymphoma: spectrum of 
imaging features. ISRN Radiol 2013;2013:483069

40. Nishino M, Hayakawa K, Minami M, Yamamoto A, Ueda H, Takasu K. Primary retroperitoneal neoplasms: CT and MR imaging findings with anatomic and pathologic diagnostic clues. Radiographics 2003;23:45-57

41. Demirkazik FB, Akhan O, Ozmen MN, Akata D. US and CT findings in the diagnosis of tuberculous peritonitis. Acta Radiol 1996;37:517-520

42. Ha HK, Jung JI, Lee MS, Choi BG, Lee MG, Kim YH, et al. CT differentiation of tuberculous peritonitis and peritoneal carcinomatosis. AJR Am J Roentgenol 1996;167:743-748

43. Na-ChiangMai W, Pojchamarnwiputh S, Lertprasertsuke N, Chitapanarux T. CT findings of tuberculous peritonitis. Singapore Med J 2008;49:488-491

44. Levy AD, Shaw JC, Sobin LH. Secondary tumors and tumorlike lesions of the peritoneal cavity: imaging features with pathologic correlation. Radiographics 2009;29:347-373

45. Walkey MM, Friedman AC, Sohotra P, Radecki PD. CT manifestations of peritoneal carcinomatosis. AJR Am J Roentgenol 1988;150:1035-1041

46. Karaosmanoglu D, Karcaaltincaba M, Oguz B, Akata D, Ozmen M, Akhan O. CT findings of lymphoma with peritoneal, omental and mesenteric involvement: peritoneal lymphomatosis. Eur J Radiol 2009;71:313317

47. Cabral FC, Krajewski KM, Kim KW, Ramaiya NH, Jagannathan JP. Peritoneal lymphomatosis: CT and PET/ CT findings and how to differentiate between carcinomatosis and sarcomatosis. Cancer Imaging 2013;13: $162-170$

48. Selikoff IJ, Hammond EC, Seidman H. Latency of asbestos disease among insulation workers in the United States and Canada. Cancer 1980;46:2736-2740

49. Arleo EK, Schwartz PE, Hui P, McCarthy S. Review of leiomyoma variants. AJR Am J Roentgenol 2015; 205:912-921

\section{유사하거나 특이한 CT 소견을 보이는 장간막 병변}

차화진 · 황지영*· 홍성숙·이은지·김현주·장윤우

장간막은 장을 복벽에 고정시키는 두 겹의 복막으로 이루어진 구조물이다. 장간막 질환들은 성인에서 다양하고 비특이적인 임상증상을 일으킬 수 있으며 때로는 다른 이유로 시행한 영 상검사에서 우연히 발견되기도 한다. CT는 장간막 질환을 진단하는 데 필수적인 역할을 한 다. 장간막 질환은 CT에서 고형 종괴, 낭성 종괴 그리고 국소적 또는 미만성 침윤 등의 다양 한 영상의학적 소견을 보인다. 일부 질환들은 특징적인 소견을 나타내지만 어떤 질환들은 유 사한 소견을 보여 감별진단이 어려울 수 있다. 따라서 장간막을 침범하는 질환의 영상의학적 소견에 대하여 이해하는 것은 장간막 질환을 정확하게 진단하고 적절한 치료를 결정하는 데 중요하다. 